\title{
Proposed indicators to measure adherence to and effects of rights-based family planning: Resource guide
}

\author{
Kelsey Wright \\ Population Council \\ Karen Hardee \\ Population Council
}

Follow this and additional works at: https://knowledgecommons.popcouncil.org/departments_sbsr-rh

Part of the Demography, Population, and Ecology Commons, Family, Life Course, and Society Commons, International Public Health Commons, and the Women's Health Commons How does access to this work benefit you? Let us know!

\section{Recommended Citation}

Wright, Kelsey and Karen Hardee. 2015. "Proposed indicators to measure adherence to and effects of rights-based family planning: Resource guide." Washington, DC: Population Council, The Evidence Project. 


\section{Proposed Indicators to Measure Adherence to and Effects of Rights-Based Family Planning}

\section{RESOURCE GUIDE}

Kelsey Wright | Karen Hardee

November 2015 
The Evidence Project

Population Council

4301 Connecticut Ave. NW, Suite 280

Washington, DC 20008 USA

tel +12022379400

evidneceproject.popcouncil.org

USAID

The Evidence Project is made possible by the generous support of the American people through the United States Agency for International Development (USAID) under the terms of cooperative agreement no. AID-

OAA-A-13-00087. The contents of this document are the sole responsibility of the Evidence Project and Population Council and do not necessarily reflect the views of USAID or the United States Government.

Evidence

The Evidence Project uses implementation science-the strategic generation, translation, and use of evidence-to strengthen and scale up family planning and reproductive health programs to reduce unintended pregnancies worldwide. The Evidence Project is led by the Population Council in partnership with INDEPTH Network, International Planned Parenthood Federation, Management Sciences for Health, PATH, Population Reference Bureau, and a University Research Network.

Published in November 2015.

Suggested citation: Wright, Kelsey and Karen Hardee. 2015. "Proposed Indicators to Measure Adherence to and Effects of Rights-Based Family Planning," Resource Guide. Washington, DC: Population Council, The Evidence Project.

(C) 2015 The Population Council, Inc. 


\section{Introduction}

The 2012 London Summit on Family Planning established the goal of expanding access to family planning programs by 120 million additional women and girls by 2020. This ambitious goal calls attention to the need for family planning information and services to be delivered in ways that are voluntary and respect human rights. While human rights have been codified and affirmed in declarations, conventions, and treaties endorsed by governments and the international community (United Nations 1968; UNFPA 2014), the focus on operationalizing rights in family planning programs, however, is in an early stage of development. There is no single definition of a human rights-based approach in family planning; yet a number of resources have been developed to guide programming (Kumar and Hardee 2015). Rights and rights principles specifically related to family planning identified from these resources include: 1) acceptability, 2) accessibility, 3) accountability 4) agency/autonomy 5) availability, 6) empowerment, 7) equity, 8) informed choice, 9) informed decisionmaking, 10) non-discrimination, 11) participation, 12) privacy and confidentiality, and 13) quality (FP2020 2014; WHO 2014).

But with the recent emergence of global numeric benchmarks for family planning programs, there is the risk that the focus will move away from these rights and rights principles. Monitoring systems are not in place to reliably track the implementation of rights-based approaches and rights omissions and violations, in part because we do not know which metrics accurately measure adherence to and effects of rights-based approaches to family planning. Without reliable and validated measurements, rights are under threat of being left out of global agendas.

Many global groups are currently working on defining and conceptualizing measurement methods for a rights-based approach to family planning programs, such as the WHO Advisory Group on Strengthening Family Planning's Normative Standards for Monitoring, Evaluation and Accountability; FP2020; and Performance, Monitoring and Accountability 2020. The Evidence Project has taken the lead on compiling indicators or measurements of human rights and family planning proposed by these global groups. These metrics have been compiled in the following table that is being used as a resource in helping Uganda operationalize the rights language in its Family Planning Costed Implementation Plan (FP CIP).

\section{Use of the Indicator Table in Uganda}

The Evidence Project, together with IPPF's Sustainable Networks Project (SIFPO2), are taking part in a groundbreaking process in Uganda spearheaded by the Ministry of Health $(\mathrm{MOH})$ and Reproductive Health Uganda (RHU) to develop an action plan for a rights-based approach to family planning in support of the MOH's FP CIP. The country's FP CIP (2015-2020), developed to reflect its FP2020 goals, explicitly pledges to protect and fulfill human rights in the provision of family planning services (Uganda FP CIP 2014). The Uganda FP CIP repeatedly states its dedication to ensuring that family planning services are provided according to human rights and quality of care standards. The introduction explicitly states the country's commitment to provide rights-based family planning information and services to improve the health and well-being of the population (Uganda FP CIP 2014, pp. 1). 
"On the one hand, these buman rights issues are intrinsic to a life of dignity and well-being, thus meriting the government's protection. On the other hand, the non-fulfillment of these rights bears an important cost on the country's economic and social development for current and future generations." (pp. 1)

Uganda has taken on the challenge of closing the gap between what is written and how services and programs are delivered. During two high-level workshops in 2015, co-hosted by the Uganda Ministry of Health and RHU, stakeholders identified four priority human rights issues to address in an action plan that is being drafted by a task force which emerged from the workshops.

To facilitate this process, the Evidence Project undertook a mapping of potential rights indicators or areas of measurement of human rights and family planning based on recommendations from global stakeholders. The resulting table shows for each proposed indicator or measurement, which of the 13 rights or rights principles (mentioned above) the metric measures, the source of the metric, and under what thematic area it could be found in a FP CIP. The table was used with Ugandan stakeholders to help them identify key metrics to include in the project monitoring plan for the Uganda FP CIP. Thus the table is an important resource in helping countries or organizations move from rights principles embodied in planning documents to monitoring adherence to and the effects of rights-based approaches to family planning.

\section{References}

FP2020 Rights and Empowerment Working Group. 2014. Family Planning 2020: Rights and Empowerment Principles for Family Planning. Washington, DC: FP2020.

Kumar, Jan, and Karen Hardee. 2015. “Rights-Based Family Planning: 10 Resources to Guide Programming,” Resource Guide. Washington, DC: Population Council, The Evidence Project.

Uganda Family Planning Costed Implementation Plan, 2015-2020. 2014. Ministry of Health, Uganda. Kampala, Uganda.

United Nations. 1968. Final Act of the International Conference on Human Rights, Tehran 22 April to 13 May 1968. United Nations, New York, NY.

UNFPA. 2014. International Conference on Population and Development Programme of Action, Twentieth Anniversary Edition. United Nations Population Fund. New York, NY.

WHO. 2014. Ensuring Human Rights in the Provision of Contraceptive Information and Services. Geneva: WHO. 


\section{Proposed Indicators of Human Rights and Family Planning}

\begin{tabular}{|c|c|c|c|c|c|c|c|c|c|c|c|c|c|c|c|}
\hline $\begin{array}{l}\text { PROPOSED INDICATOR/ } \\
\text { AREA OF MEASUREMENT }\end{array}$ & 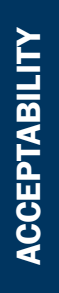 & 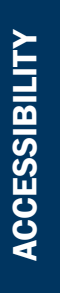 & 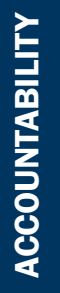 & 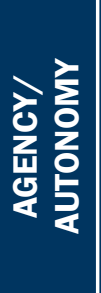 & 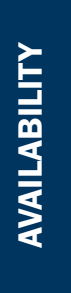 & $\frac{5}{2}$ & 를 & 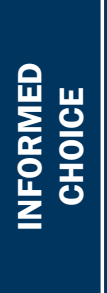 & 밀 & 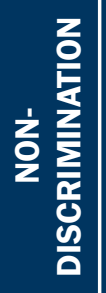 & 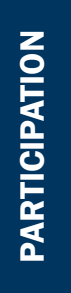 & 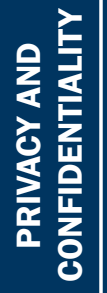 & $\frac{2}{2}$ & NOTES & SOURCES \\
\hline \multicolumn{16}{|c|}{ DEMAND CREATION } \\
\hline $\begin{array}{l}\text { Contact of non-users with family } \\
\text { planning providers }^{1}\end{array}$ & & & & & & & & & & & & & & $\begin{array}{l}\text { See WHO, } 2014 \text { for } \\
\text { definition of numerator and } \\
\text { denominator. }\end{array}$ & - WHO \\
\hline $\begin{array}{l}\text { Individual (women) awareness } \\
\text { of rights and confidence in } \\
\text { ability to exercise their rights: } \\
\text { - Freely decide whether, } \\
\text { when, how many children } \\
\text { to have } \\
\text { - To quality FP services and } \\
\text { information } \\
\text { - Non-discrimination }\end{array}$ & & & & & & & & & & & & & & $\begin{array}{l}\text { Requires operationalization to } \\
\text { become measurable indicator. } \\
\text { Could be developed as an } \\
\text { index measure. }\end{array}$ & - FP2020 R\&E group \\
\hline $\begin{array}{l}\text { Mean score on informed choice } \\
\text { index }{ }^{1}\end{array}$ & & & & & & & & & & & & & $\sqrt{ }$ & $\begin{array}{l}\text { Informed choice index } \\
\text { includes questions to } \\
\text { current users of modern } \\
\text { contraception about whether } \\
\text { they were informed about } \\
\text { side effects, what to do if side } \\
\text { effects are experienced, and } \\
\text { if they were informed of other } \\
\text { methods. Some measures } \\
\text { include the number of women } \\
\text { informed of the permanence } \\
\text { of sterilization. The index } \\
\text { measures FP2020 core } \\
\text { indicators } 11 \text { and } 15 .\end{array}$ & $\begin{array}{l}\text { - FP2020 R\&E group } \\
\text { - WHO } \\
\text { - Guttmacher } \\
\text { Institute } \\
\text { - MEASURE } \\
\text { Evaluation PRH } \\
\text { FP/RH Indicator } \\
\text { Database }\end{array}$ \\
\hline $\begin{array}{l}\text { Number/percent of schools } \\
\text { offering comprehensive sex } \\
\text { education }\end{array}$ & & & & & & & & & & & & & & & $\begin{array}{l}\text { - Guttmacher } \\
\text { - MEASURE } \\
\text { Evaluation PRH } \\
\text { FP/RH Indicator } \\
\text { Database }\end{array}$ \\
\hline
\end{tabular}


PROPOSED INDICATOR/

AREA OF MEASUREMENT

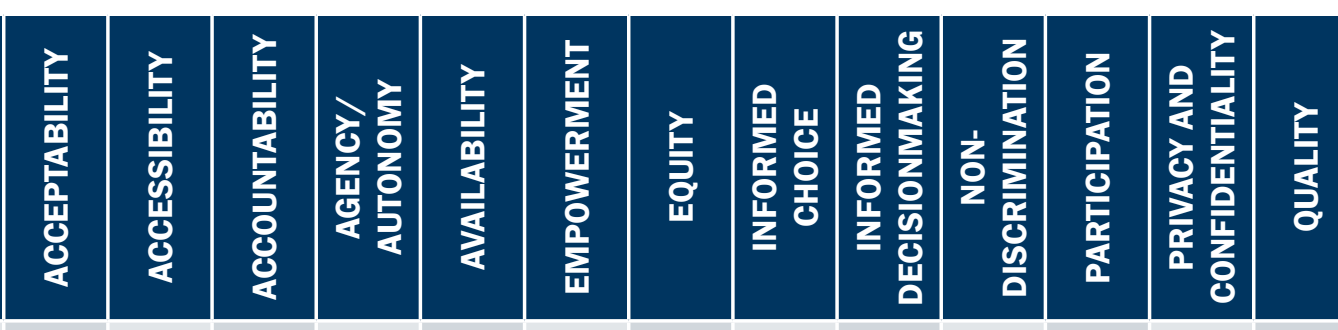

NOTES

SOURCES

Percent of women who make

family planning decisions alone or jointly with their husbands ${ }^{1,3}$

Ratio of the percentage of demand satisfied by a modern method in the poorest wealth quintile (01) to the percentage in the wealthiest quintile (Q5) $-Q 1: Q 5^{1}$

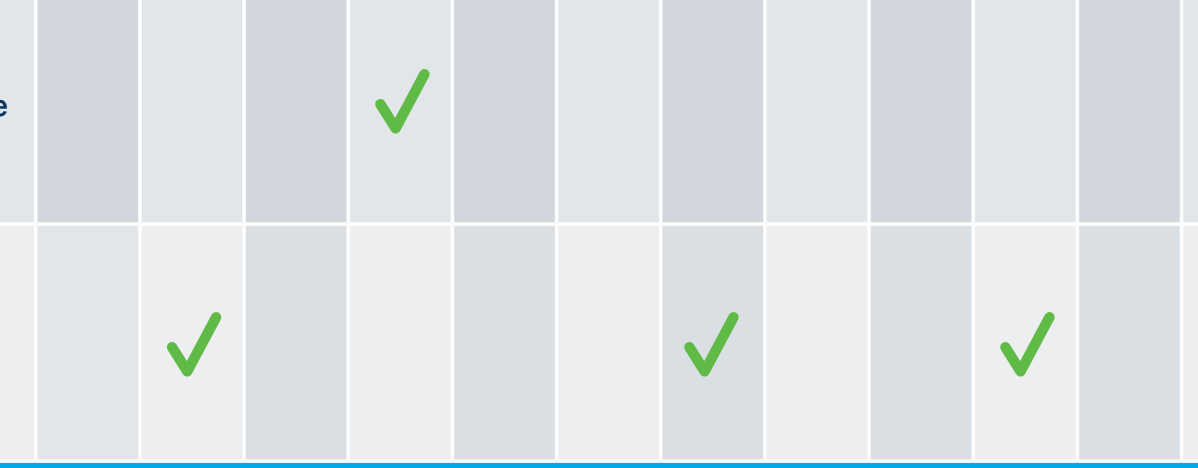

- FP2020 R\&E group

- Track20

- MEASURE

Evaluation $\mathrm{PRH}$

$\mathrm{FP} / \mathrm{RH}$ Indicator Database

Can be measured using

CPR and unmet need. Data - WHO

requires disaggregation by

- FP2020 R\&E group wealth quintiles.

\section{SERVICE DELIVERY AND ACCESS}

Availability of sites equipped to provide easy access for removal of implants and IUDs, including the services and supplies to support women's ability to easily switch between methods if they chose

Contraceptive user satisfaction with services

Extent to which FP is integrated into post-partum, post-abortion, and HIV/AIDS services (e.g., through referral, within same facility, fully integrated within same visit).

Extent to which programs are meeting the needs of marginalized and special groups, including women in conflict/disaster settings ${ }^{3}$

Facilities meeting quality of care standards

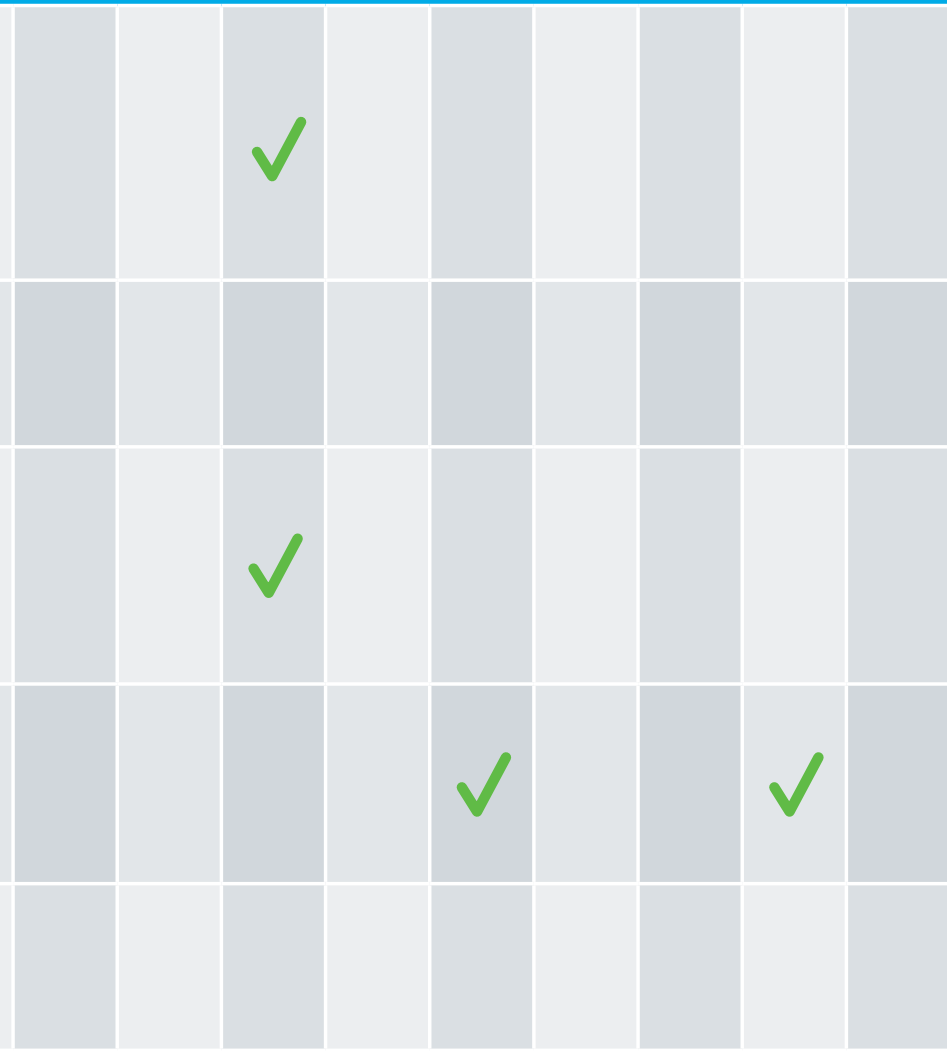

Requires operationalization to become measurable indicator; some or part of this measure could be enumerated using standard service delivery statistics

See WHO, 2014 for

definition of numerator and . WHO denominator

- FP2020 R\&E group

See MEASURE Evaluation PRH $\begin{array}{ll}\text { - } & \text { MEASURE } \\ & \text { Evaluation PRH }\end{array}$ FP/RH Indicator Database for FP/RH Indicator relevant indicators

Database

Requires population based survey that identifies

both user and non-use

- FP2020 R\&E group characteristics

See WHO, 2014 for

definition of numerator and denominator 
PROPOSED INDICATOR/

AREA OF MEASUREMENT

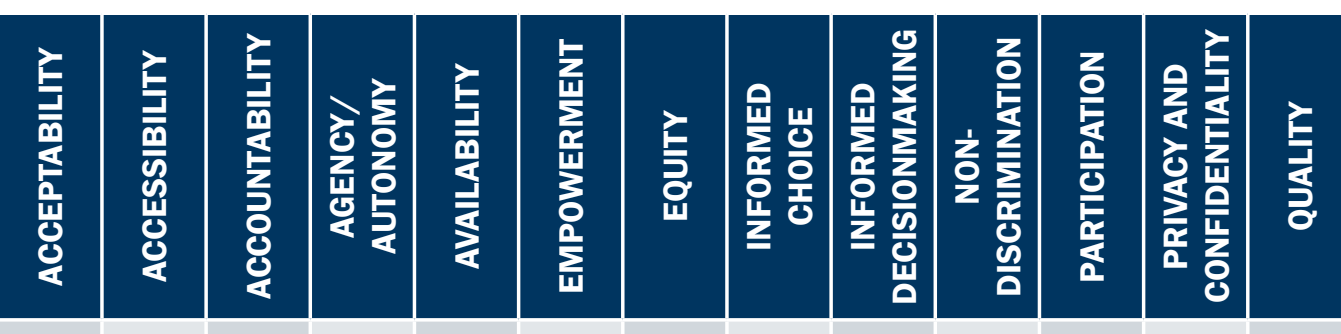

NOTES

SOURCES

Indicator reflective of

disrespect/abuse in access to

contraceptive information and

services

Number of contraceptive service

delivery points

Percent of facilities reliably

offering a range of methods,

encompassing 4 categories of

contraceptive methods: short

term; long acting reversible;

permanent; and emergency

contraception $^{2}$

Perceptions of services/

program (satisfaction, respect

and trust)

Programs/Facilities seeking and utilizing service user feedback in some form ${ }^{2,3}$

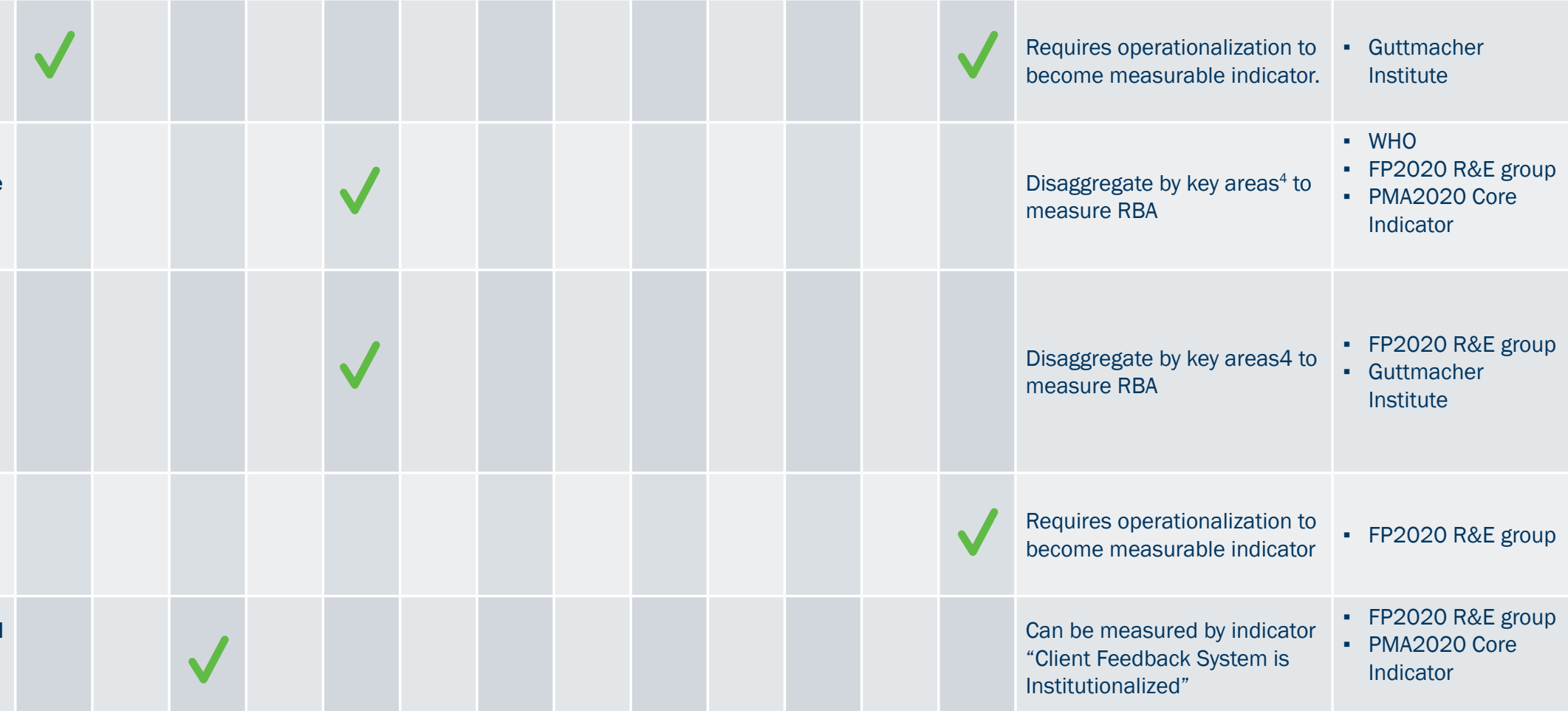

CONTRACEPTIVE SECURITY

Existence of a government budget line item for the procurement of contraceptives ${ }^{5}$

Percent of facilities that experienced a stockout at any point during a given time period

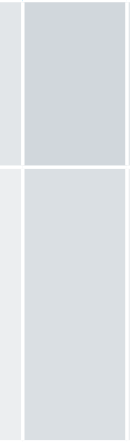

- MEASURE

Evaluation PRH

$\mathrm{FP} / \mathrm{RH}$ Indicator

Database

- FP2020 R\&E group

- MEASURE

Uganda HMIS uses similar

Evaluation PRH

indicator with Depo Provera as

$\mathrm{FP} / \mathrm{RH}$ Indicato

Database

- Uganda HMIS 
PROPOSED INDICATOR/

AREA OF MEASUREMENT

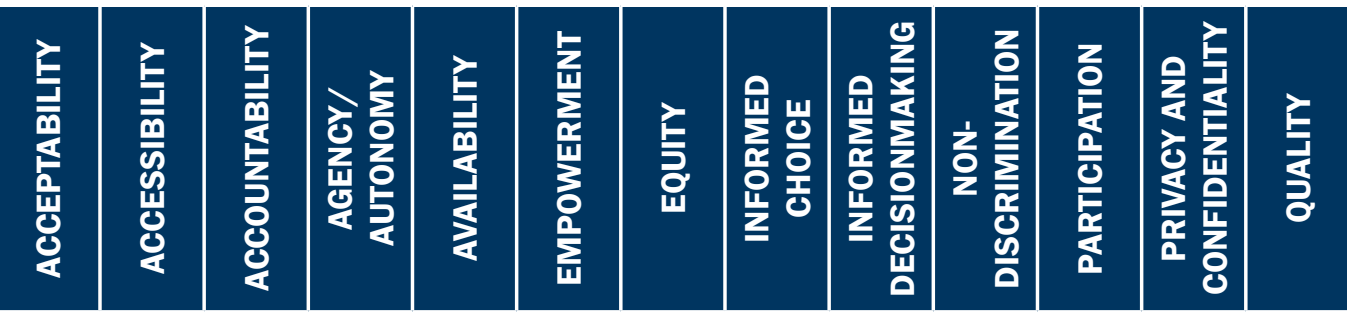

NOTES

SOURCES

FINANCING

Annual expenditure on FP from government domestic budget

The financial management system produces accurate, timely information

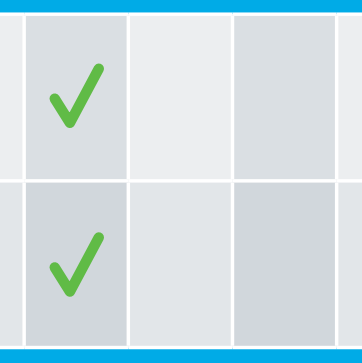

- Track20

- MEASURE

Evaluation PRH

$\mathrm{FP} / \mathrm{RH}$ Indicator

Database

POLICY AND ENABLING ENVIRONMENT

Does the community provide an enabling environment for women to exercise their FP choices

Whether SRH rights are integrated into law and policy (i.e., access to contraceptive services without spousal or parental/guardian authorization/notification and without age limitation

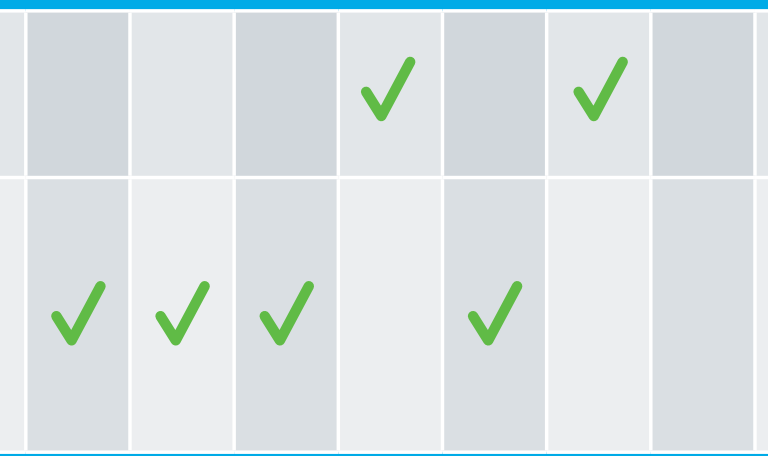

Requires operationalization to become measurable indicator

FP2020 R\&E group

Requires operationalization to become measurable indicator

Guttmache

Institute

\section{STEWARDSHIP, MANAGEMENT, AND ACCOUNTABILITY}

A system for quality assurance has been institutionalized

Extent to which accountability mechanisms are in place to identify and provide remedies for rights violations

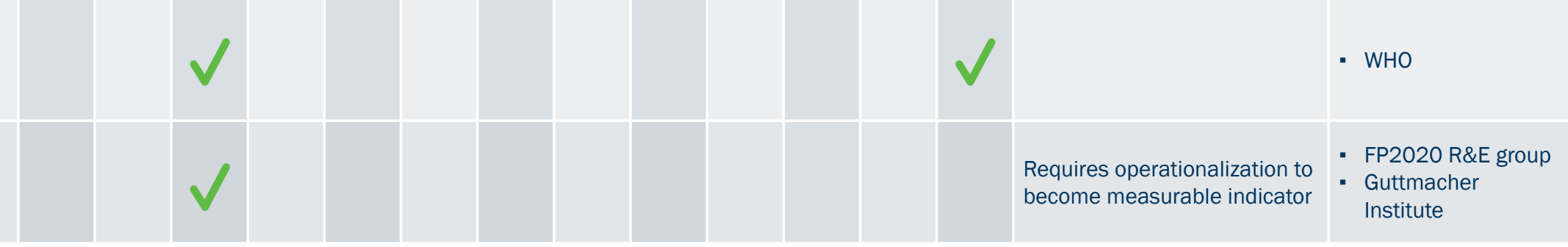


PROPOSED INDICATOR/ AREA OF MEASUREMENT

Adolescent Birth Rate ${ }^{1}$

Contraceptive discontinuation

due to lack of access

Contraceptive method mix ${ }^{1,2}$

Contraceptive prevalence rate (CPR) ${ }^{1,2}$

Unmet need for family

planning ${ }^{1,2}$

Extent to which country adopts/ follows/utilizes WHO medical

eligibility criteria, including for adolescents

Among women who want to space or limit, what are reasons for non-use of family planning services and non-use of

contraception (divided by those that discontinued vs. those that never used)

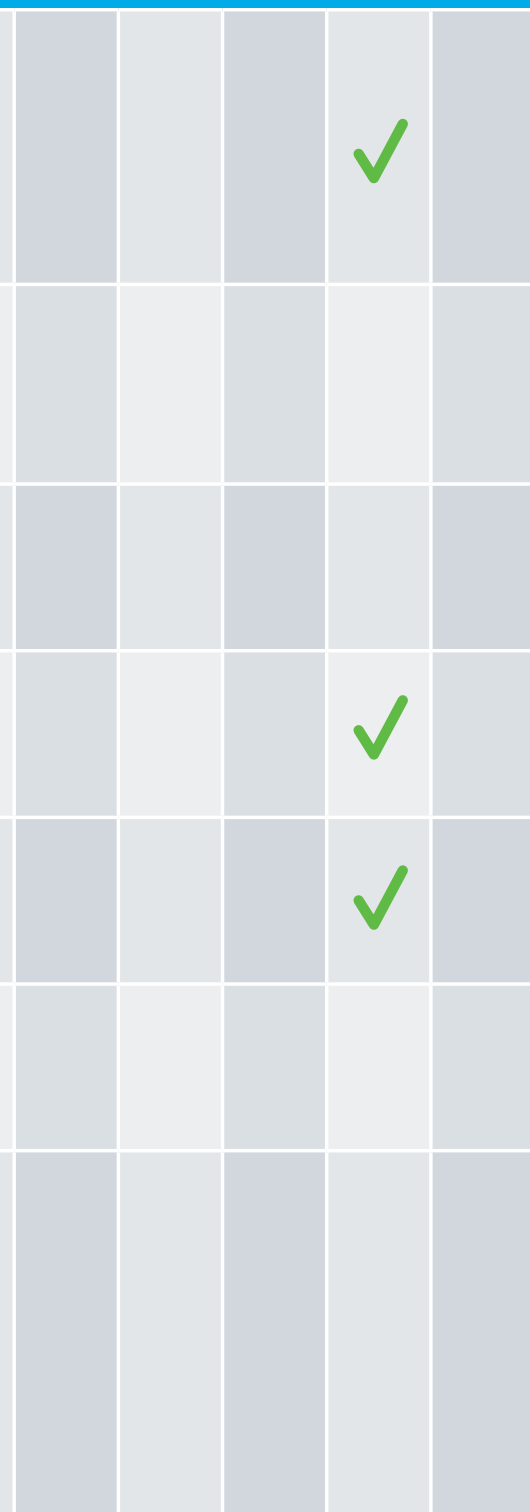

- Guttmacher

- PMA2020

- Track20

Can be disaggregated by

- MEASURE relevant categories.

Evaluation PRH

$\mathrm{FP} / \mathrm{RH}$ Indicator

Database

Can be measured through the indicators "Contraception - WHO

Discontinuation Rate" when disaggregated by "Reason for

- FP2020 R\&E group discontinuation"

\section{- $\mathrm{WHO}$}

- Track20

- WHO

- Track20

Disaggregate by key areas4 to measure RBA

- FP2020 R\&E group

Requires operationalization to become measurable indicator

- FP2020 R\&E group

Non-Use of contraception can be captured through the following indicators:

- Discontinuation

- WHO

(disaggregated by spacing or limiting and reason)

- Unmet need (disaggregated by spacing and limiting and reason) 


\section{The Evidence Project}

Population Council

4301 Connecticut Avenue, NW, Suite 280

Washington, DC 20008 USA

tel +12022379400

evidenceproject.popcouncil.org 